日臨外会誌 $63(8), 1919-1923,2002$

症例

腫瘍増大の経過を追えた小腸 gastrointestinal stromal tumor の 1 例

新村病院, 金沢大学大学院医学系研究科癌局所制御学*

黒 阪 慶幸新村康二 藤 村 隆*

腫場增大の経過を追えた小腸 GIST, uncommitted type の1例を経験したので報告す る.

症例は65歳の男性で, 左下腹部に充実性腫瘤を指摘され入院となる. CT にて左下腹部 $に 9 \mathrm{~cm}$ 大の境界明瞭な充実性腫瘤を認めた。1 年 8 力月前のCTでは同部に腫瘍を認 めず，ダブリングタイムは約70日と概算できた。，小腸の間葉系腫湯の診断で，腫瘍を含 め空腸部分切除を行った。腫湯細胞は紡鍾形で束状配列し多数の核分裂像を認めた．免 疫染色では c-kit protein と CD34にのみ陽性を示し GIST, uncommitted type, malignant そ診断された. 自験例は強い増殖能を持つ高度悪性の GIST と考えられた.

GISTs の治療は手術が基本であるが, 有効な治療薬も開発された。適切な術式や新治 療薬の適応を決定するため, さらに症例を重ね GISTs の生物学的特性を明らかにしてい く必要があると思われた。

索引用語：gastrointestinal stromal tumor (GIST), 小晹腫場

緒 言

Gastrointestinal stromal tumors（略称 GISTs）は， 消化管壁の間質細胞に由来する間葉系腫瘍の総称であ る.その内カハール介在細胞由来とされる“uncommitted type”は，臨床的に悪性と考えられ不良な予後を示 すものがある.

今回私どもは, 腫瘍增大の経過を追えた小腸 GIST, uncommitted type の 1 例を経験したので文献的考察 を加え報告する。

$$
\text { 症例 }
$$

症例：65歳, 男性.

主訴：左下腹部腫瘤。

家族歴：特記すべきことなし。

既往歴：32歳, 虫垂切除術, 40歳, 高血圧, 60歳,

腹部大動脈瘤置換術。

現病歴：2001年 1 月31日, 高血圧外来での診察時に 左下腹部に腫瘤を指摘され精查加療を目的に入院とな 3.

入院時現症：身長 $164 \mathrm{~cm}$, 体重 $59 \mathrm{~kg}$ ，貧血，黄㾝な

2002 年 3 月 29 日受付 2002 年 5 月 28 日採用

〈所属施設住所〉

₹920-2104 石川県石川郡鶴来町月橋町 $722-12$
く，表在リンパ節も触知しなかった．臍下左側に手拳 大の圧痛や可動性のない充実性腫瘤を触知した。腹水 は認めなかった。

入院時検查成績: $\mathrm{Cr} 2.4 \mathrm{mg} / \mathrm{dl}, \mathrm{BUN} 32.2 \mathrm{mg} / \mathrm{dl}$ と 軽度の腎障害をみたが, 腫湯マーカーも含め他には異 常值を認めなかった。

小腸造影所見：左下腹部に腫浯による滑らかな圧排 所見を認めるが，腸管に狭窄や拡張はなく通過は良好 であった（図 1 )。

腹部 CT 所見：2001年 2 月の CT では, 腹壁に接し て境界明瞭な $9 \mathrm{~cm}$ 大の内部に low density な部分を 持つ類円形の充実性腫瘤を認めた(図 2 a ). 1999年 5 月の CT では同部位に腫愓を認めない(図 2 b)，1 年 8 カ月の短い期間に腫湯は増大しており，そのダブリ ングタイムは約70日と概算できた。

腹部 MRI 所見：T 1 で低信号, T 2 で高信号の内部 に壊死をみる腫瘤を認めた。明らかな周囲への浸潤は みられなかった（図 3).

上部消化管内視鏡, 大腸内視鏡と $\mathrm{Ga}$ スキャンでは 異常所見を認めなかった。

手術所見：2001年 2 月23日，小腸より発生した間葉 系腫湟の診断で開腹術を行った。大動脈溜置換術後の 癒着をみたが，腹水や腹膜播種はなかった。トライッ 


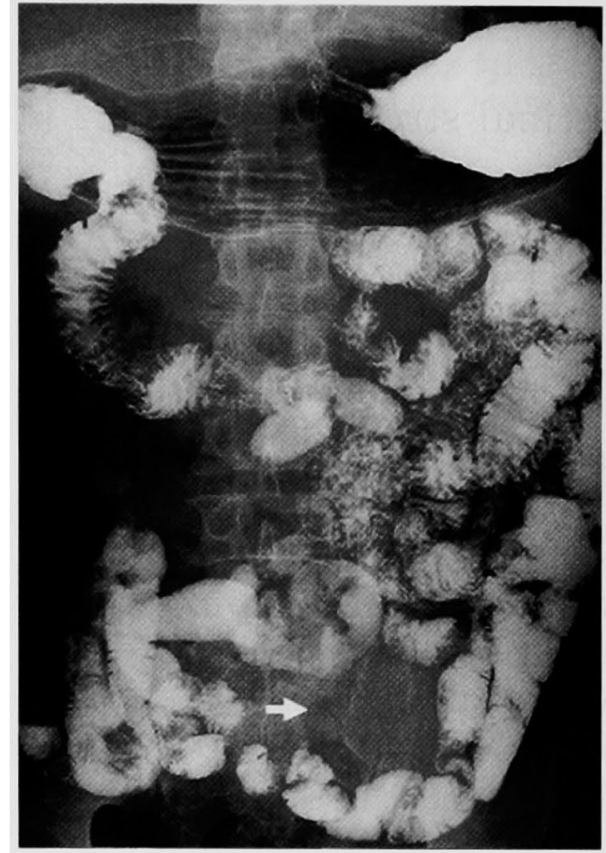

図 1 小腸造影所見：左下腹部に腫瘍による滑 らかな圧排所見 (矢印)を認めるが，狭管や拡 張はなく通過は良好であった。

靶帯より約 $80 \mathrm{~cm}$ 肛門側の空腸間膜側に, 被膜に多く の新生血管をみる手拳大の充実性腫瘤を涊めた。尾側 には鷄卵大の娘結節を伴っていた。リンパ節に腫大な く郭清は行わず，腫瘍を含め $35 \mathrm{~cm}$ の空腸を切除した。

摘出標本：塊状充実性で弾性軟の腫㴦は, $8.5 \times$ $6.0 \times 5.5 \mathrm{~cm}$ 大で, 割面では大量の出血と壊死を認め た. その大部分が小腸間膜内にあり，一部が小腸固有 筋層と平滑な境界を持って連結していた． $3.0 \times 2.5 \times$ $1.5 \mathrm{~cm}$ 大で主腫瘍と同じ性状の娘結節を, 主腫暘の右 尾側に認めた，娘結節は，被膜の一部を主腫場と共有 していたが連続性はなかった(図4)，少数認めた標本 中のリンパ節に転移はみられなかった。

病理組織学的所見：H-E 染色では, 紡錘形の腫瘍細 胞が密に束状配列し，核異形は高度で一視野に多数の 核分裂像を認めた（図５）。

免疫組織学的所見：免疫組織学的には, c-kit protein にびまん性に強陽性(図 6 a)，CD34に陽性を示し たが(図 6 b), desmin と s-100蛋白は陰性であり平滑 筋やシュワン細胞への分化はみられなかった。

以上より高度な核異形と多数の核分裂像の所見も合 わせ, GIST, uncommitted type, malignant と診断し た. 全身状態良好で再発なく術後 1 年を経過している。

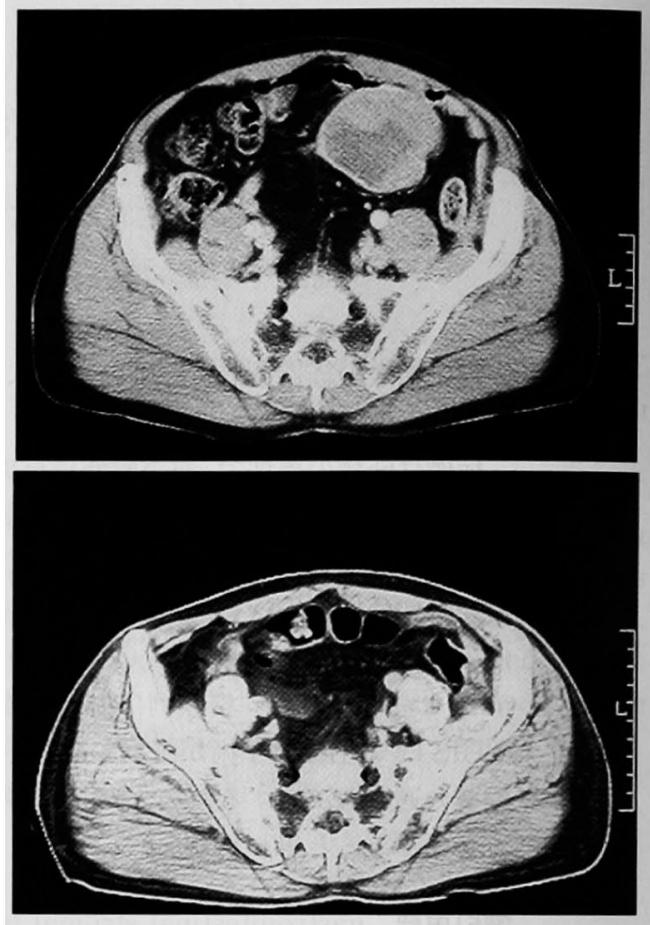

図 2 腹部 CT 所見：a )2001年 2 月の CT では， 9 $\mathrm{cm}$ 大の内部に low な部分を持つ充実性腫瘤を認 めた。b)1999年 5 月のCT では同部に腫瘤を認め ない.

$$
\frac{a}{b}
$$

\section{考察}

消化管に発生する間葉系腫湯の GISTs は, 免疫組織 学的な検索により Rosai' が分類した 4 タイプに分け 診断することが可能となった.すなわち, (1) desmin が 陽性となる筋原性の smooth muscle type, (2) $\mathrm{s}-100$ 蛋 白が陽性となる神経原性の neural type, (3)筋原性・神 経原性の双方の特徽を有する combined smooth muscle-neural type, (4)どちらにも分化傾向を示さず CD34や c-kit proteinが陽性となる uncommitted type の 4 種である.

自験例は CD34と c-kit proteinにのみ陽性であり， 前述の uncommitted type と診断された。

CD34は,一定の分化を示さない未熟な間葉系細胞に 発現するが，いったんその分化の方向が決まるとみら れなくなるマーカーである2!. また c-kit protein は, tyrosin kinase を持続的に活性化し細胞增殖を刺激す る前癌遺伝子 KIT の突然変異に関連したマーカーて ある.ほとんどの GISTsにこの突然変異は発現し特徵 的であり,変異 KITにより充進した tyrosin kinase 活 


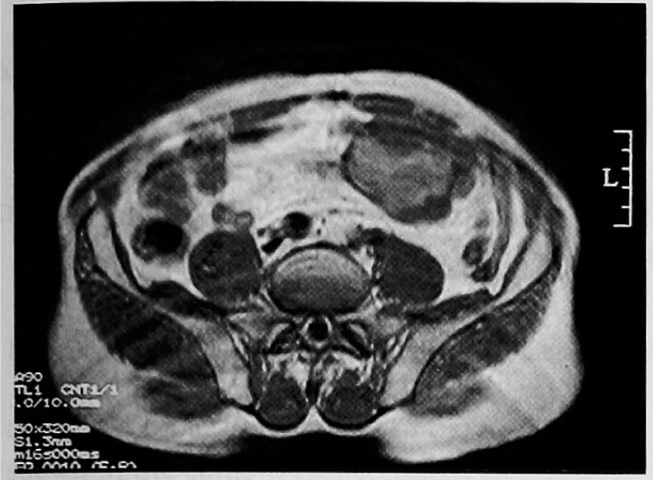

图 3 腹部 MRI 所見 ( $\mathrm{T} 1$ 強調)：T I で低信号, $\mathrm{T}$ 2 で高信号の内部に壊死をみる腫瘤を認めた。

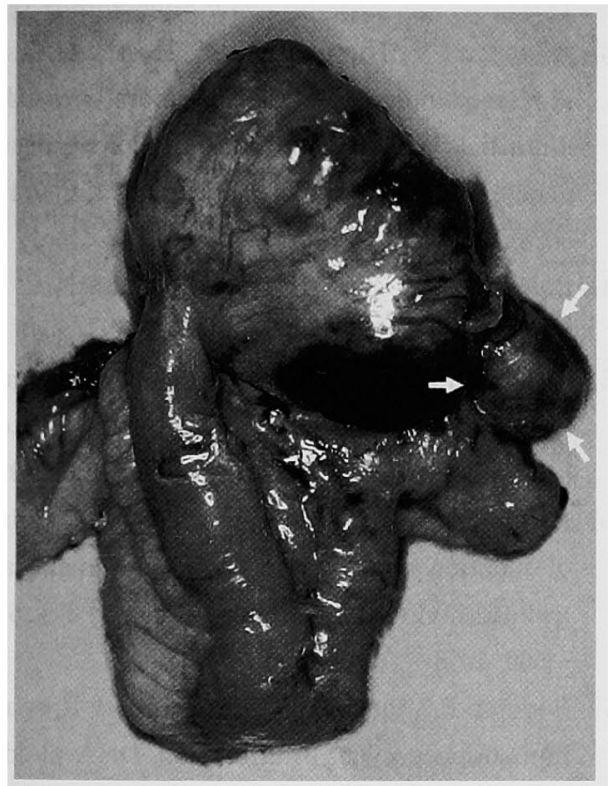

図 4 摘出標本: 塊状充実性の腫瘍は8.5 $6.0 \times 5.5 \mathrm{~cm}$ 大で, その右尾側に3.0×2.5×1.5 $\mathrm{cm}$ 大の娘結節（矢印）を認めた。

性がGISTsの発生と増殖に重要な役割を演じている と考えられている3(4).

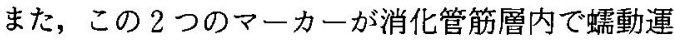
動のペースメーカーとして側くカハール介在細胞に陽 性であることから, uncommitted type はこのカハー ル介在細胞の幹細胞より発生するのではないかと考え られている5)6).

Uncommitted type は, GISTs の約 7\%を占め臨床 的には悪性腫演とみなされている7). 当症例は 1 年 8 カ月間に $500 \mathrm{~g}$ を越え手拳大まで増大しており腫暘の

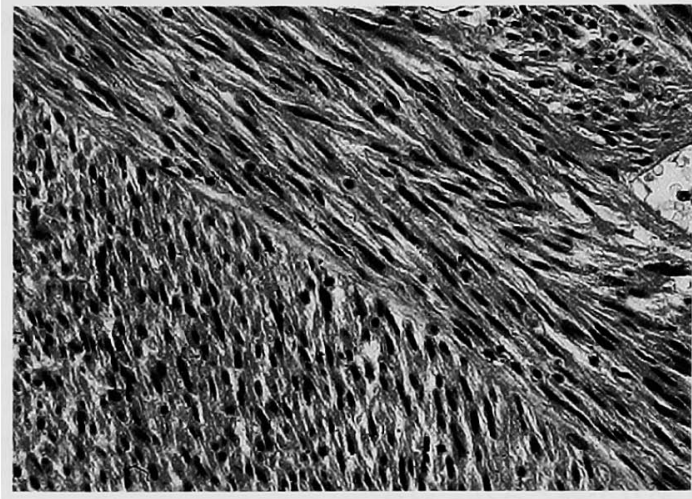

図 5 病理組織学的所見：紡錘形の腫瘍紐胞が密に束状 配列し，核異形は高度で多数の核分裂像を認めた $(\mathrm{H}-$ E 染色, $\times 100)$.

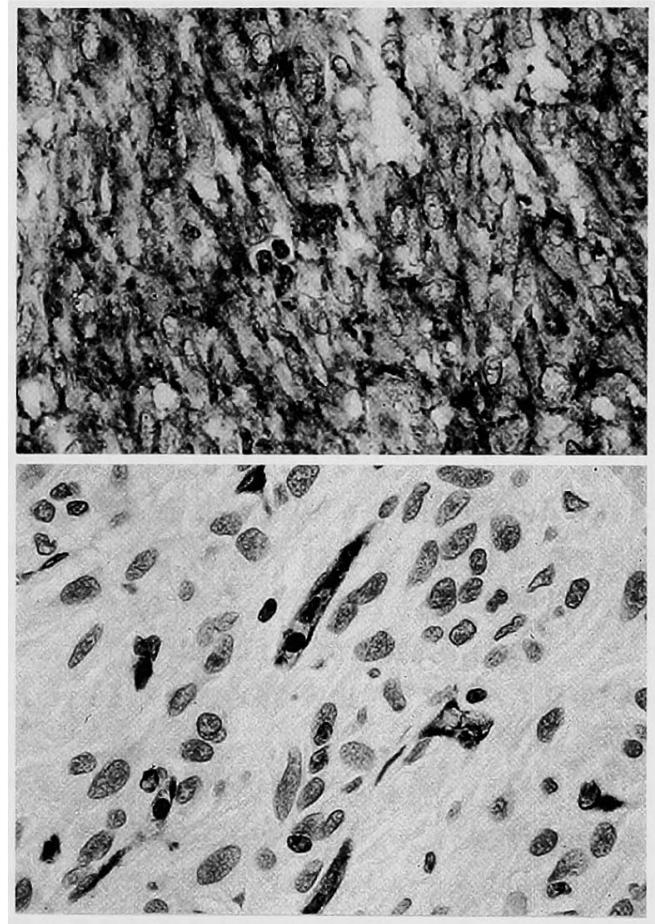

図 6 免废組織学的所見：a） c-kit protein にびま ん性に強陽性を示した（c-kit 免疫染色, $\times 200)$.

b) CD34に陽性を示した (CD34免疫染色, ×200).

$\frac{\mathrm{a}}{\mathrm{b}}$

ダブリングタイムは概算すると約70日と短く，c-kit protein が強陽性に発現していたことや多くの核分裂 像を認めたことを合わせ強い増殖能を持つことが示唆 された.これらのことより自験例は高度悪性の GIST 
と考えられ，厳重な術後経過観察を行っているが術後 1 年を再発なく良好に経過している。

空腸や回腸の GISTs は, 部位的に術前確定診断を得 ることは困難である，小腸に関して CT・MRI などの 検查て内部に出血や中心壊死を伴う境界明暸な充実性 の腫瘤をみた場合，GISTsをも考慮し対応することが 必要と思われた。

治療は手術が第一選択であり，播種させないよう舜 護的に操作し正常組織を含む腫瘍の完全切除を行うこ とが肝要である、リンパ節郭清については，転移は稀 であり不要とされている゙.

GISTsに対し従来の化学療法や放射線療法は無効 であり，肝転移や腹膜播種をみる進行例や術後の再発 例に対する有効な治療法の開発が待たれていた。

経口薬であるSTI571は，慢性骨䯣性白血病の非常 に有効な治療薬として開発された細胞のシグナル伝详 阻害物質である。この薬剂は tyrosin kinase を選択的 に阻害し，慢性骨髄性白血病の bcr-abl や悪性腫瘍の 増殖に関与する PDGF や KIT のレセプターをブロッ クする作用を有する。変異 KITにより元進した tyrosin kinase 活性が発生と増殖に密接に関与する GISTs の治療薬として有効であるとされ ${ }^{34)}$, 培責細胞 を用いた実験により実証されだ．また第37回米国癌 治療学会総会において GISTsに対するSTI571のア メリカとヨーロッパに扔ける初期臨床試験の結果が報 告され，その高い有効性が臨床的にも確認された。特 に米国の第 II 相試験では，腫瘍細胞に c-kit の発現が 確認された症例に投与され $59 \%$ と半数以上に PR が得 られた。さらに欧米に扔いて STI5710 GISTsに対す る適応を明らかにするため多くの臨床試験が行わ扎て いる9!.

以上のように，有効な新治療薬が開発され臨床での 使用が可能となったが, GISTsの病因や病態など生物 学的特性は明らかでなく，標準的な診断基準と治療法 も確立されていない. GISTsに対する術式や新治療薬 の適応を決定するため，腫瘍悪性度の評価や転移・再 発の予測などさらに症例を重ね検討し明らかにしてい く必要があると思われた。

\section{結語}

腫瘍増大の経過を追えた小腸 GIST, uncommitted type の 1 例を経験したので文献的考察を加え報告し た。

稿を終えるに当たり，御指導を頂いた武川病理研究所武 川昭男先生に深謝致します。

\section{References}

1) Rọsai J : Stromal tumors. Ackerman's surgical pathology, $8^{\text {th }}$ ed., Mosby-year Book, Inc, St. Louis, 1996, p645-647

2) Rijin MVD, Hendeickson MR, Rouse RV, et al : CD34 expression by gastrointestinal tract stromal tumors. Hum Pathol 25:766-771, 1994

3) Allander SV, Nupponen NN, Hostetter G, et al : Gastrointestinal stromal tumors with KIT mutations exhibit a remarkably homogeneous gene expression profile. Cancer Res 15 : 86248628,2001

4) Demetri GD: Targeting c-kit mutations in solid tumors. Semin Oncol 28:19-26, 2001

5) Kindblom LG, Remotti HE, Aldenborg F, et al : Gastrointestinal pacemaker cell tumor (GIPACT). Am J Pathol 152 : 1259-1269, 1998

6) Hirota $S$, Isozaki $K$, Moriyama $Y$, et al: Gainof-function mutations of c-kit in human gastrointestinal stromal tumors. Science $279: 577$ $-580,1998$

7) Rudolph $P$, Gloeckner $K$, Parawaresch $R$, et al : Immunophenotype, proliferation, DNA ploidy, and biological behavior or gastrointestinal stromal tumors. Hum Pathol 29:791-800, 1998

8) Tuveson DA, Willis NA, Jacks T, et al : STI571 inactivation of the gastrointestinal stromal tumor c-kit oncoprotein : biological and clinical implications. Oncogene 20:5054-5058, 2001

9) Berman J, O'Leary TJ : Gastrointestinal stromal tumor workshop. Hum Pathol $32: 578$ $-582,2001$ 


\title{
A CASE OF GASTROINTESTINAL STROMAL TUMOR OF THE JEJUNUM OBSERVING ITS GROWTH
}

\author{
Yoshiyuki KUROSAKA, Kouji SHINMURA and Takashi FUJIMURA* \\ Shinmura Hospital \\ *Surgical Oncology, Division of Cancer Medicine, Kanazawa University
}

We report a case of gastrointestinal stromal tumor (GIST) of the jejunum, observing its growth.

A 65-year-old man admitted for a solid mass in the left lower abdomen was found in abdominal computed tomography (CT) to have a solid $9.0 \mathrm{~cm}$ tumor in the left lower abciomen. Since no mass was shown in the same CT slice taken 20 months ago, doubling time for this tumor appeared to be about 70 days. Under a diagnosis of a mesenchymal tumor of the small bowel, we conducted partial resection of the jejunum including of the tumor. $\mathrm{H}-\mathrm{E}$ staining showed dense fasicular proliferation of spindle-shaped tumor cells in bundles and many nuclear divisions in a single field. Immunohistochemical studies showed that tumor cells were positive for c-KIT protein and CD34 but negative for other markers. This tumor was diagnosed as uncommitted malignant GIST considered high-grade malignancy with aggressive proliferation.

Surgical resection of the tumor is the principal treatment for GIST, but new drugs highly effective against GIST have been developed. To ensure appropriate surgical procedure and optimal indications of new drugs, we must understand the unique biology of GIST clarified by more clinicopathological studies. 